\title{
Teacher satisfaction at the educational placement of students with special educational needs ${ }^{1}$
}

\author{
Timo Saloviita ${ }^{2}$ \\ Markku Leskinen ${ }^{3}$
}

\begin{abstract}
This study conducted a large-scale survey to investigate the satisfaction of Finnish primary school teachers toward the current educational placement of their students with special educational needs (SEN). Teachers were asked to recommend the most suitable educational placement for each of their SEN students from a pool of six alternatives: a mainstream classroom, part-time special education, a special classroom in the mainstream school, a special school, a state special school, or an institution. Data were obtained from 980 students representing 68 schools. The results showed that, in the majority of cases, teachers recommended a different level to the current level of placement for their SEN students. Teachers in the mainstream classrooms mostly recommended special classrooms, while teachers of the special education classrooms frequently recommended special schools, and teachers of the special schools often recommended state special schools or special education classrooms. A less restrictive environment was recommended for $20 \%$ and a more restrictive environment was recommended for 33\% of the students. The results are interpreted in terms of organizational selection.
\end{abstract}

Keywords: school sociology; special education; referral to special education; teacher satisfaction; Finland

\section{Introduction}

In Finland, as in many other countries, the placement in special education is at least partly determined by the diagnosis of the student with special educational needs (SEN). During the eighties, the Finnish special education system still relied on separate special education curriculums for several diagnostic categories. As this situation changed in the nineties, the current Finnish school legislation contains only a few elements of medical labelling and instead stresses noncategorical, individual curriculum planning based on identifying the unique needs of each child. The basis of this planning is the individual education plan, which was enforced in Finland in the late nineties (The Basic Education Act, 1998). However, this policy of non-categorical special education has been partly compromised by the local schools' freedom to choose how to categorize their classrooms. This has led to the emergence of a large quantity of diagnostically titled classrooms such as autism, Asperger's, and dysphasia classrooms.

Educational placement based on medical diagnosis is often considered inaccurate because large differences exist between children sharing a common diagnosis (Algozzine \& Ysseldyke, 1983;

\footnotetext{
${ }^{1}$ This study was partly funded by the Finnish National Board of Education.

2 Ph.D., University of Jyvaskyla, Faculty of Education, Department of Teacher Education, timo.saloviita@jyu.fi

${ }^{3}$ D.Ed., University of Jyvaskyla, Faculty of Education, Department of Education, markku.leskinen@jyu.fi
} 
Saloviita, T., \& Leskinen, M. (2016). Teacher satisfaction toward the educational placement of students with special educational needs. International Journal of Human Sciences, 13(1), 1792-1796. doi:10.14687/ijhs.v13i1.3675

Hallahan \& Kauffman, 1977; Reschly, Tilly, \& Grimes, 1998; Ysseldyke, 1987). For example, a meta-analysis of 58 relevant studies confirmed that diagnostic categories of students with learning disabilities, mild intellectual disabilities, and emotional or behavioral disabilities could be reliably differentiated according to certain measures; whereas, group differences according to some other measures remained small (Sabornie, Cullinan, Osborne, \& Brock, 2005).

Besides diagnostic categories, special education environments can be grouped according to their restrictiveness. Ordered from the least restrictive to the most restrictive environment, an example list could contain placement in full-time mainstream schools, part-time special education, a special classroom in the mainstream school, a special school, and an institution. The idea of the succession of environments from least to most restrictive was presented by Reynolds (1962) as a hierarchical cascade model of special education. Typically, the more restrictive the placement is, the more divergent from "normal" the children are considered to be, the more expensive is the program, the more children are separated from ordinary school life, and the higher are demands for highly specialized personnel (Reynolds, 1962).

According to Reynolds (1962), placing the child in the appropriate level of the cascade is ideally based on their individual need of services. No child should be placed in a level that supersedes his or her need of restrictiveness. This principle came to be known as the principle of "least restrictive environment" (LRE) in the U.S. school legislation since 1975 (Crockett \& Kauffman, 1999). The weakness of this principle, of course, lies in the difficulty in finding objective criteria for the right level of restrictiveness.

Because of some internal weaknesses of the diagnosis-based approach and the theory of LRE, other, more sociological, theories have emerged to explain educational placements of children with SEN. One theory is based on the funding model of education. An international analysis has confirmed that the funding of special education is important for explaining the popularity of placement alternatives (Meijer, 1999). A comparison of 17 European countries indicated that direct state funding of special education classrooms and special schools caused more students to be moved to more restrictive environments (Meijer, 1999).

Another promising approach to explain the transfer of students from one educational setting to another is to apply concepts from organizational sociology. According to Etzioni (1964), as social organizations tend to select their members, they can save costs that would otherwise be needed for the control and socialization of their members. Schools providing compulsory education are organizations with an obligation to accept the whole age cohort of children inside their walls. The selection pressure becomes obvious when considering that approximately $5 \%$ of members are usually responsible for $95 \%$ of all serious disorders observed in any organization (Etzioni, 1964; Horner, Sugai, Todd, \& Lewis-Palmer, 2005, 362). Accordingly, some writers have interpreted the schools' placement policy in special education as an example of organizational selection (Kivinen \& Kivirauma, 1988; Skrtic, 1991). If this frame of reference is used, the selection of students for different levels of special education can be seen as a kind of competition between the teachers in which teachers with the best resources are most successful in avoiding unwanted placements. Better resources may manifest as higher formal teacher qualification or higher informal social position in the organization. For example, several studies have shown that students with intellectual disabilities are the least preferred student category among teachers (Bowman, 1986; Forlin, 1995; Moberg, 2003). In accordance with the competition hypothesis, the teachers of this category have the lowest teacher qualification requirements in Finland (Government Decree 105, 2012).

If the theory of organizational selection is correct, many teachers are likely to express dissatisfaction about the current placement of their SEN students because the competition between teachers by necessity produces also losers. The present study is designed to test this hypothesis. Teachers were thus administered a survey to establish which level of placement they consider the most suitable alternative for each of their students with SEN. 
Saloviita, T., \& Leskinen, M. (2016). Teacher satisfaction toward the educational placement of students with special educational needs. International Journal of Human Sciences, 13(1), 1792-1796. doi:10.14687/ijhs.v13i1.3675

\section{Participants}

\section{Method}

The sample of this study consisted of students with SEN in Finnish primary schools run by the partners who participated in a research project financed by the National Board of Education. Data were obtained from 65 basic schools representing 23 local municipalities and three stateowned special schools for students with hearing or visual impairment. Out of the original sample, six local municipalities, three state-owned schools, and five state-owned special schools declined to participate. Overall, data were obtained for 980 students aged between 6 and 18 years, giving a mean age of 12 . Of those students, $70 \%$ were male and 30\% female. The informant was a female teacher in $73 \%$ of cases and male in $27 \%$ of cases. The mean age of the teachers was 42 .

\section{Procedure}

The data were collected as part of a project by the National Board of Education concerning the development of the quality of special education. The partners in the project were the stateowned special schools and a sample of local municipalities responsible for the running of primary schools. The municipalities were selected based on a number of criteria which stressed, among other things, diversity of circumstances and a local interest in partaking in the study. Project partners chosen for this study were only those responsible for the operation of one or more primary schools, which included 29 municipalities, three state-owned comprehensive schools, and eight state-owned special schools.

Data were collected through a survey, which was sent to a contact person of each partner organization. The contact person distributed the survey forms to local schools or individual teachers. The survey concerning each student with SEN was completed by his major or homeroom teacher.

\section{Instrument}

The survey asked questions to obtain brief demographic data on each student with SEN from their teacher. The teacher was also asked to recommend an educational placement in answer to the following question: "Mark the educational placement which, in your view, would be the most suitable alternative for this particular student." The teachers could choose from six groups ordered according to their assumed restrictiveness: (1) a full-time regular class, (2) part-time special education, (3) a special education classroom in a regular school, (4) a special school, (5) a stateowned special school, or (6) an institution.

State-owned special schools were boarding schools which accepted students from all over the country. They were originally intended for students with visual or hearing impairments, but their entrance criteria were gradually become looser. The term institution was not defined for the teachers; it was only added as a possible option for the recommended educational placement.

\section{Results}

The results concerning the present and recommended environment are presented in Table 1. In general, the teachers were dissatisfied with the current level of educational environment for their students. Of all students with SEN, a level other than their present level was recommended for $47 \%$ of students. The greatest dissatisfaction was reported by teachers of special classes and municipal special schools. Of all special class placements, $58 \%$ were considered to be wrong by the special class teachers. For the municipal special schools the same number was $52 \%$. The least amount of dissatisfaction was reported by the teachers of the state special schools $(14 \%)$. However, this data was distorted by the director of one school with 47 students who instructed the teachers to record all existing placements as the best options, thus preventing the teachers from making individual evaluations. When only the schools of local municipalities were counted, a level other than a student's present level of placement was recommended for $53 \%$ of the cases. Of these, teachers recommended a less restrictive environment for $20 \%$ of the cases and a more restrictive environment for $33 \%$ of the cases. 
Saloviita, T., \& Leskinen, M. (2016). Teacher satisfaction toward the educational placement of students with special educational needs. International Journal of Human Sciences, 13(1), 1792-1796. doi:10.14687/ijhs.v13i1.3675

Table 1. Current and recommended teaching environment for students with SEN

\begin{tabular}{llllllllll}
\hline Current environment & $\mathrm{N}$ & \multicolumn{9}{c}{ Total } & \multicolumn{9}{c}{ Recommended environment \% } & \multicolumn{2}{c}{ Total } \\
\cline { 4 - 8 } & & $\%$ & 1. & 2. & 3. & 4. & 5. & 6. & $\%$ \\
\hline 1. Mainstream class & 12 & 2 & 50 & 8 & 42 & - & - & - & 100 \\
2. Part-time special & 88 & 16 & 6 & 65 & 21 & 8 & 1 & - & 101 \\
3. Special class & 354 & 24 & 1 & 14 & 42 & 42 & 1 & - & 100 \\
4. Special school & 387 & 47 & 1 & 13 & 16 & 48 & 23 & - & 101 \\
5. State special school & 139 & 11 & 1 & 1 & - & - & 86 & 12 & 100 \\
6. Institution & - & - & - & - & - & - & - & - & - \\
Total & 980 & 100 & 2 & 16 & 24 & 35 & 22 & 2 & 101 \\
\hline
\end{tabular}

\section{Discussion}

Only $47 \%$ of the students with SEN were considered to have been placed in the most suitable educational level by their homeroom teachers in basic schools. This is a large amount of dissatisfaction considering that original placement decisions were normally based on the opinions of several professionals and experts in the school organization such as teachers, psychologists, physicians, social workers, physiotherapists, and speech therapists. The children's parents were also usually involved in the discussions. The decision process typically contained psychological tests, and if disagreements arose, the decision was confirmed by a multi-professional administrative team.

The teachers' recommendations were directed more often toward more restrictive environments $(33 \%)$ than less restrictive environments $(20 \%)$. The frequent wish to transfer the student into another setting was confirmed both in mainstream and special education settings. The results showed that the school organization contained several levels between which student transfers was negotiated. Thus, the step from regular education to special education was not the only one in which the clash between teachers could occur.

The results of this study confirm the existence of organizational selection as a factor behind student placements. This is obvious from the fact that teachers expressed considerable dissatisfaction with the current placement of their students with SEN despite the complex and multistage process through which the best possible solution was sought. A large corpus of previous studies has attempted to find associations of teacher attitudes towards inclusive education with various child-related, teacher-related, and environment-related factors (Avramidis \& Norwich, 2002; de Boer, Pijl, \& Minnaert, 2011; Scruggs \& Mastropieri, 1996). Future studies are recommended to analyse the teachers' actual dissatisfaction towards special educational placements in connection with the relevant background factors.

\section{References}

Algozzine, B., \& Ysseldyke, J. (1983). Learning disabilities as a subset of school failure: The oversophistication of a concept. Exceptional Children, 50, 242-246.

Avramidis, E., \& Norwich, B. (2002). Teachers' attitudes towards integration/inclusion: A review of the literature. European Journal of Special Needs Education, 17, 129-147.

Basic Education Act of 1998, 628 \$S 1-56 (2003). Retrieved from http://www.finlex.fi/fi/laki/ajantasa/1998/19980628?search\%5Btype \%5D=pika\&search $\% 5 \mathrm{Bpika} \% 5 \mathrm{D}=$ perusopetuslaki

Bowman, I. (1986). Teacher training and the integration of handicapped pupils: Some findings from a fourteen nation UNESCO Study. European Journal of Special Needs Education, 1, 29-38.

Crockett, J. B., \& Kauffman, J. M. (1999). The least restrictive environment: Its origins and interpretations in special education. London: Lawrence Earlbaum. 

educational needs. International Journal of Human Sciences, 13(1), 1792-1796. doi:10.14687/ijhs.v13i1.3675

de Boer, A., Pijl, S. J., \& Minnaert, A. (2011). Regular primary schoolteachers' attitudes towards inclusive education: A review of the literature. International Journal of Inclusive Education, 15, 331-53.View article: DOI: 10.1080/13603110903030089

Etzioni, A. (1964). Modern organizations. Englewood Cliffs, NJ: Prentice-Hall.

Forlin, C. (1995). Educators' beliefs about inclusive practices in Western Australia. British Journal of Special Education, 22, 179-185.

Government Decree Amending the Regulation on the Eligibility Criteria for Teaching, 105 SS 8-17 (2012). Retrieved from http://www.finlex.fi/fi/laki/alkup/2012/20120105

Hallahan, D. P., \& Kauffman, J. M. (1977). Labels, categories, behaviors: ED, LD, and EMR reconsidered. The Journal of Special Education, 11, 139-149.

Horner, R. H., Sugai, G., Todd, A. W., \& Lewis-Palmer, T. (2005). Schoolwide positive behaviour support. In L. M. Bambara \& L. Kern (Eds.), Individualized supports for students with problem behaviours (pp. 359-390). New York, NY: Guilford Press.

Kivinen, O., \& Kivirauma, J. (1988) Classification, selection and schooling. Special education in the Finnish school system in the 20th century. Sociological Studies Series A No. 13. Turku: University of Turku.

Meijer, J. W. (Ed.). (1999). Financing of special needs education: A seventeen country study of the relation between financing of special needs education and integration. Middelfart, Denmark: European Agency for Development in Special Needs Education.

Moberg, S. (2003). Education for all in the north and the south: Teachers' attitudes towards inclusive education in Finland and Zambia. Education and Training in Developmental Disabilities, $38,417-428$.

Reschly, D. J., Tilly, W. D., \& Grimes, J. P. (1998). Functional and noncategorical identification and intervention in special education. Iowa State Department of Education (ED 434454). Retrieved from http://eric.ed.gov/?id=ED434454

Reynolds, M. C. (1962). A framework for considering some issues in special education. Exceptional Children, 28, 367-370.

Sabornie, E. J., Cullinan, D., Osborne, S. S., \& Brock, L. B. (2005). Intellectual, academic, and behavioural functioning of students with high-incidence disabilities: A cross-categorical meta-analysis. Exceptional Children, 72, 47-63.

Scruggs, T. E., \& Mastropieri, M. A. (1996). Teacher perceptions of mainstreaming/inclusion, 1958-1995: A research synthesis. Exceptional Children, 63, 59-74.

Skrtic, T. M. (1991). Behind special education. Critical analysis of professional culture and school organization. Denver, CO: Love Publishing.

Ysseldyke, J. E. (1987). Classification of handicapped students. In M. C. Wang, M. C. Reynolds \& H. J. Walberg (Eds.). Handbook of special education: Research and practice, Vol 1, Learner characteristics and adaptive education (pp. 253-271). Oxford, England: Pergamon Press. 